\title{
First record of the genus Everniastrum Sipman (Parmeliaceae, lichenized Ascomycota) for the state of Paraná, Brazil
}

Alice da Cruz Lima Gerlach ${ }^{1,3}$, Emerson Luiz Gumboski² and Sionara Eliasaro ${ }^{1}$

Received: 17 August, 2012. Accepted: 23 September, 2013

\begin{abstract}
Everniastrum is a pantropical genus that has been recorded for the Brazilian states of Minas Gerais, Rio de Janeiro, São Paulo and Rio Grande do Sul. In this work, we present the first records of E. cirrhatum and E. vexans for the Brazilian state of Paraná. Comments and illustrations are provided.
\end{abstract}

Key words: lichenized Ascomycota, lichens, Mycota, upper montane rain forest

Everniastrum Sipman occurs in tropical mountain areas (Hale 1976, Sipman 1980), usually on bryophytes and in humid localities where mist and rain prevail for most of the year (Sipman 1980). It is a pantropical genus with centers of speciation in Asia, Central America and South America (Elix 1993), occurring mainly in Mexico and in the central Andes region, specifically in Ecuador and Peru (Sipman 1986).

The oldest known reference to this genus in Brazil is from Culberson \& Culberson (1981), who mentioned E. cirrhatum (Fr.) Sipman for the mountainous region of the state of Rio de Janeiro. The genus is also known to occur in the states of Minas Gerais and São Paulo (Ribeiro 1998), as well as in the state of Rio Grande do Sul (Fleig 1985).

In the present study, we provide the first record of the genus for the state of Paraná, where we identified two species: E. cirrhatum and E. vexans (W.L. Culb. \& C.F. Culb.) Sipman.

We collected specimens during lichenological expeditions to Caratuva Peak, near the municipality of Antonina, which is in the Serra do Mar coastal mountain range, in the state of Paraná, at an elevation of $1850 \mathrm{~m}$. The specimens were preserved and deposited in the Herbarium of the Botany Department of the Federal University of Paraná (code, UPCB). The morphological and anatomical analyses were performed according to Gerlach \& Eliasaro (2012). For the identification of secondary metabolites, we employed coloration tests of the cortex and medulla (Taylor 1967,
1968), together with thin layer chromatography (Culberson \& Ammann 1979; Elix \& Ernst-Russell 1993).

Everniastrum cirrhatum (Fr.) Sipman, Mycotaxon 26: 237. 1986.

$\equiv$ Parmelia cirrhata Fr., Syst. Orb. Veg. (Lundae) 1:283.1825.

Fig. $1 \mathrm{~A}$ and $1 \mathrm{~B}$

Description: Sipman (1980) and Yánez-Ayabaca (2009).

Coloration tests: upper cortex, $\mathrm{K}+$ yellow; medulla, $\mathrm{K}+$ yellow $\rightarrow$ red, C- and KC-.

Substances of taxonomic value detected by thin layer chromatography: atranorin, salazinic acid and a non-identified fatty acid with an $\mathrm{Rf}_{\mathrm{c}} \approx 47$.

Everniastrum cirrhatum can be recognized by the absence of propagules and the presence of salazinic acid in the medulla. In the specimen analyzed, the conidia were bifusiform, measuring 5.0-5.5 (-6.0) $\times 1.0 \mu \mathrm{m}$, similar to those described by Ribeiro (1998) and Yánez-Ayabaca (2009), who reported $E$. cirrhatum conidia measuring 5.0-6.0 $\times 1.0$ $\mu \mathrm{m}$ and 5.0-5.5 (-6.0) $\times 0.8 \mu \mathrm{m}$, respectively. Culberson \& Culberson (1981) and Sipman (1980), however, described the conidia of this genus as bacilliform to short filiform, measuring 5.0-7.0 $\times<1.0 \mu \mathrm{m}$ and $6.0-7.0 \times 0.5 \mu \mathrm{m}$, respectively. The lobes of the specimen analyzed here measured $0.5-1.5 \mathrm{~mm}$, slightly narrower than those described by Sipman (1980) and Yánez-Ayabaca (2009), who reported lobe widths of 0.8-2.0 (-3.0) $\mathrm{mm}$ and (0.7-)

\footnotetext{
${ }^{1}$ Universidade Federal do Paraná, Departamento de Botânica, Laboratório de Liquenologia, Curitiba, PR, Brazil

${ }^{2}$ Universidade Federal do Rio Grande do Sul, Programa de Pós-Graduação em Botânica, Porto Alegre, RS, Brazil

${ }^{3}$ Author for correspondence: alice_gerlach@yahoo.com.br
} 


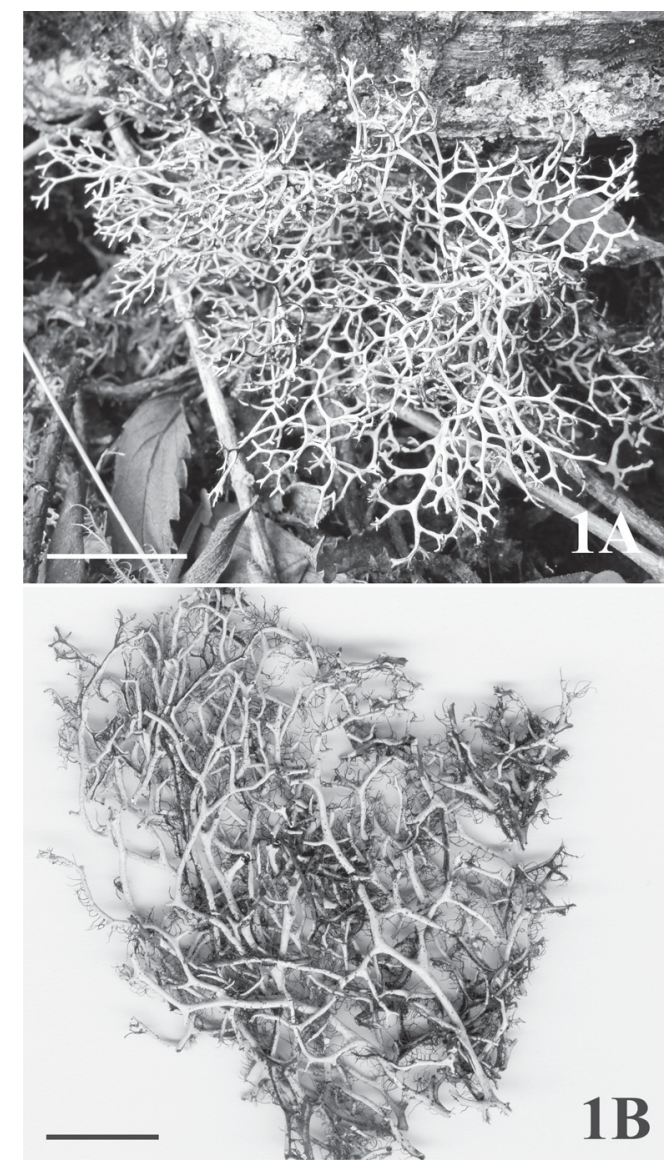

Figure 1. Everniastrum cirrhatum (Fr.) Sipman (A. Gerlach et al. 725). A) E. cirrhatum in the field. B) E. cirrhatum in the laboratory. (Scale bar $=1 \mathrm{~cm}$ )

1.0-2.6 mm, respectively. Although both of those authors mentioned the presence of numerous apothecia in the material examined, those structures were not observed in the specimen evaluated in the present study.

Although Everniastrum cirrhatum is not well known in Brazil, Osorio \& Fleig (1986) stated that the species is likely undersampled and probably widely distributed in the mountainous regions of Brazil. Everniastrum cirrhatum is corticolous and occurs together with E. vexans on humid slopes among bryophytes.

Distribution: Widely distributed in Asia, Africa and the Americas (Sipman 1980). In South America, it is cited for Argentina, Colombia, Peru and Venezuela (Sipman 1980); for Bolivia (Feuerer et al. 1998); and for Chile and Ecuador (Culberson \& Culberson 1981). In Brazil, it occurs in the states of Rio de Janeiro (Culberson \& Culberson 1981), Rio Grande do Sul (Fleig 1985) and São Paulo (Ribeiro 1998). Material examined: BRAZIL. Paraná: Antonina, Pico Caratuva, 06/VII/2011, A. Gerlach et al. 725.

Everniastrum vexans (W.L. Culb. \& C.F. Culb.) Sipman, Mycotaxon 26: 242. 1986.

$\equiv$ Cetrariastrum vexans W.L. Culb. \& C.F. Culb., Bryologist 84(3): 294. 1981.

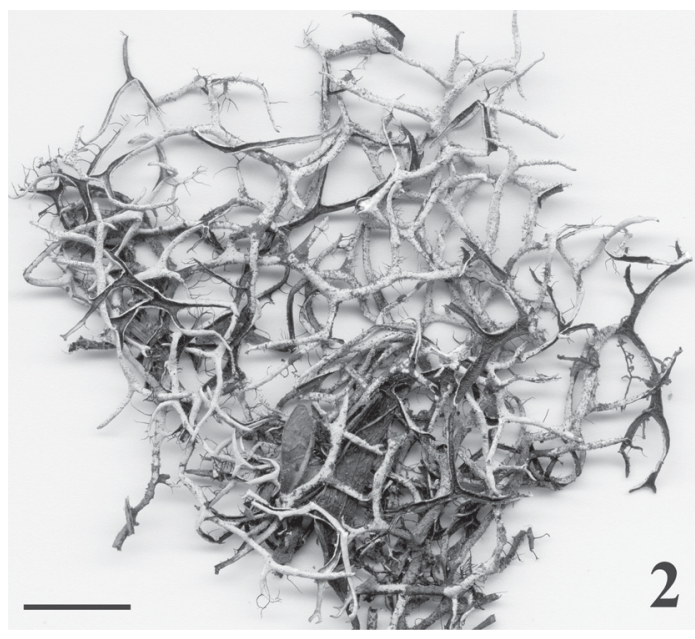

Figure 2. Everniastrum vexans (W.L. Culb. \& C.F. Culb.) Sipman (A. Gerlach et al. 687). (Scale bar $=1 \mathrm{~cm}$ )

Fig. 2

Description: Sipman (1980) and Yánez-Ayabaca (2009). Coloration tests: upper cortex, $\mathrm{K}+$ yellow; medulla, $\mathrm{K}+$ yellow $\rightarrow$ red, C- and KC-.

Substances of taxonomic value detected by thin layer chromatography: atranorin and salazinic acid.

Everniastrum vexans can be differentiated from $E$. cirrhatum basically by the presence of isidia. Like E. cirrhatum, E. vexans has abundant cilia, ranging from simple to bifurcate, 1.0-3.0 $\mathrm{mm}$ in length, which are referred to as marginal rhizines by Culberson \& Culberson (1981) and as cilia by Sipman (1980).

Culberson \& Culberson (1981) and Yánez-Ayabaca (2009) described E. vexans lobes as measuring 0.5-2.0 mm. However, in the material analyzed here, the lobes were narrower $(\leq 1.5$ $\mathrm{mm}$ in width), similar to those described by Sipman (1980), who reported a lobe width of 0.7-1.0 (-2.5) $\mathrm{mm}$.

The species was found among bryophytes on a humid slope, together with other lichenized fungi: Cladia aggregata (Sw.) Nyl, Cladonia spp. and Heterodermia sp.

Distribution: Widely distributed in Asia, Africa and the Americas (Sipman 1980). In South America, it has been cited for Argentina (Culberson \& Culberson 1981), as well as for Colombia, Ecuador and Venezuela (Sipman 1980). In Brazil, it occurs in the states of Minas Gerais and São Paulo (Ribeiro 1998), as well as in the state of Rio Grande do Sul (Fleig 1985).

Material examined: BRAZIL. Paraná: Antonina, Pico Caratuva, 06/VII/2011, A. Gerlach et al. 687.

\section{Acknowledgments}

The authors thank the lichenologist Dr. Michel Navarro Benatti, for providing some of the bibliographic references, as well as the Instituto Ambiental do Paraná (IAP, Paraná State Environmental Institute), for granting the specimen 
collection permit. This study received financial support from the Brazilian Coordenadoria de Aperfeiçoamento do Pessoal do Ensino Superior (CAPES, Office for the Advancement of Higher Education).

\section{References}

Culberson, C.F. \& Ammann, K. 1979. Standard method zur Dünnschichtchomatographie von Flechtensubstanzen. Herzogia 5: 1-24.

Culberson, W.L. \& Culberson, C.F. 1981. The genera Cetrariastrum and Concamerella (Parmeliaceae): a chemosynthetic synopsis. The Bryologist 84: 273-314.

Elix, J.A. 1993. Progress in the generic delimitation of Parmelia sensu lato lichens (Ascomycotina: Parmeliaceae) and a synoptic key to the Parmeliaceae. The Bryologist 96(3): 359-383.

Elix, J.A. \& Ernst-Russell, K.D. 1993. A catalogue of standardized thin layer chromatographic data and biosynthetic relationships for lichen substances. 2nd ed. Canberra, Australian National University Canberra.

Feuerer, T.; Ahti, T.; Vitikainen, O. 1998. Lichenological Investigations in Bolivia. Pp. 71-86. In: Marcelli M. P. \& Seaward M.R.D. (Eds.) Lichenology in Latin America: history, current knowledge and applications. São Paulo, CETESB.

Fleig, M. 1985. Estudo preliminar da família Parmeliaceae (Liquens) no Rio Grande do Sul, Brasil. Comunicações do Museu de Ciências PUCRS, Série Botânica 35: 799.
Gerlach, A.C.L. \& Eliasaro, S. 2012. Liquens parmelioides eciliados (Parmeliaceae, Ascomycota) em costões rochosos dos estados do Paraná e Santa Catarina, Brasil. Acta Botanica Brasilica 26(3): 570-584.

Hale, M.E. 1976. Synopsis of a new lichen genus Everniastrum Hale (Parmeliaceae). Mycotaxon 3: 345-353.

Osorio, H.S. \& Fleig, M. 1986. Contribution to the Lichen Flora of Brazil XVIII. Lichens from Itaimbezinho, Rio Grande do Sul, State. Comunicaciones Botánicas del Museo de Historia Natural de Montevideo 4(75): 18.

Ribeiro, C.H. 1998. A família Parmeliaceae (Ascomycota liquenizados) em regiões montanhosas dos estados de Minas Gerais, Rio de Janeiro e São Paulo. M.Sc. Dissertation, Universidade de São Paulo, São Paulo.

Sipman, H.J.M. 1980. Studies on Colombian cryptogams. X. The genus Everniastrum Hale and related taxa (Lichenes). Proceedings, Koninklijke, nederlandse akademie van wetenschappen. Series C, biological and medical sciences 83: 333-354.

Sipman, H. 1986. Notes on the lichen genus Everniastrum (Parmeliaceae). Mycotaxon 26: 235-251.

Taylor, C.J. 1967. The lichens of Ohio. Part I. Foliose lichens. The Ohio Biological Survey, Columbia, The Ohio State University Press.

Taylor, C.J. 1968. The lichens of Ohio. Part II. Fruticose and dimorphic lichens. The Ohio Biological Survey. Columbia, The Ohio State University Press.

Yánez-Ayabaca, A.A. 2009. Os gêneros Hypotrachyna e Everniastrum (Parmeliaceae, Ascomycota Liquenizados) nas Províncias de Carchi e Imbabura na Região Andina do Equador. M.Sc. Dissertation, Universidade Federal do Paraná. http://dspace.c3sl.ufpr.br/ (Acesso em 17/08/2012). 